\title{
Economic assessment of a complex of measures for the remediation of the territory from technogenic impact
}

\author{
Irina Provornaya ${ }^{1,2}$, Irina Filimonova ${ }^{1,2, *}$, Nataliya Yurkevich $^{1}$, Vasiliy Nemov $^{1,2}$ and \\ Mikhail Mishenin ${ }^{1,2}$ \\ ${ }^{1}$ Trofimuk Institute of Petroleum Geology and Geophysics of Siberian Branch Russian Academy of \\ Sciences (IPGG SB RAS), 630090, Koptug ave. 3, Novosibirsk, Russia. \\ ${ }^{2}$ Novosibirsk State University (NSU), 630090, 1 Pirogova str., Novosibirsk, Russia.
}

\begin{abstract}
In this work, an economic assessment of environmental damage to water and land resources is calculated, and the cost of a project for the reclamation of destroyed lands within the territory of the Komsomolsk gold recovery plant is determined. The object of the study is directly the territory of the enterprise, which is located in the Tisulsky municipal district of the Kemerovo region. According to our calculations, the total assessment of environmental damage from the plant's activities amounted to 458 million rubles, of which: 294 million rubles - accumulated environmental damage from water pollution; 164 million rubles accumulated environmental damage from soil pollution in the surrounding area. The cost estimate of the destroyed land reclamation project amounted to 716.7 million rubles. At the same time, income from the sale of equipment and gold mined in the territory of the tailing dump reaches 3916 million rubles.
\end{abstract}

\section{Introduction}

Currently, environmental problems are classified as "global", and the public is fully aware of their importance, specialists in all spheres of human life are beginning to actively seek possible ways to solve them. Every year, a lot of efforts and financial resources are spent on political programs, environmental norms and standards, the development of environmentally friendly products, the introduction of energy-saving technologies, etc. Ecologists and economists from all over the world try to assess the environmental damage to the natural environment caused by human economic and industrial activities, analyze the structure and qualitative characteristics of the ecological state of the territories, make forecasts of their further development and give recommendations on minimizing the negative anthropogenic impact on the environment..

The object of research in this work was the Komsomolsk gold recovery plant, where arsenopyrite gold ores were processed by cyanidation and additionally extracted gold from antimony cakes. In 2019, employees of the Institute of Petroleum Geology and Geophysics

${ }^{*}$ Corresponding author: FilimonovaIV@, list.ru 
of the SB RAS managed to measure the main chemical characteristics of the Komsomolsk tailing dump located on the territory of the plant. The interest in the enterprise from the point of view of its economic significance of the territory for the Siberian Federal District, territorial proximity, the severity of the environmental problems facing the region, and the availability of data predetermined the choice of this object as an object. research. the object and made it possible to assess the damage caused by the economic activities of the plant, as well as to develop an economically justified work plan for its elimination and restoration of the natural complex of the territory.

The purpose of this study is an economic assessment of the complex of measures for the remediation of the territory around the Komsomolsk gold recovery plant, which consists of several stages. Following the purpose of the study, the following tasks are defined in this work:

- To systematize the methodological approaches to the economic assessment of the complex of measures for the remediation of the territory from the technogenic impact;

- Estimate the cost of the project of nature restoration measures for lands affected by man-made impacts;

The main idea of the preparatory stage is reduced to the preliminary preparation of a feasibility study for the plan of reclamation work. This includes the study of future territories, the study of the specifics of the state of lands subject to reclamation, determination of the direction of reclamation, feasibility study and drafting of the work project.

The main task of the "technical" stage of reclamation, which is an important component of the land rehabilitation process, is to reproduce conditions suitable for the restoration of soil and vegetation cover and to create a basis for the subsequent "biological" phase of damage restoration work. Depending on the list of conditions, such as the further purpose of using the reclaimed soils, relief, climate, geological and hydrological characteristics of soil structures, properties of the fertile soil layer and overburden, equipment capacity and several others, a certain technology of technical reclamation is selected.

However, in almost all cases, regardless of the conditions listed, the technical stage includes the following four steps $[1,2]$ : freeing the land from garbage, household waste from the industry; burial and storage of collected waste; construction of infrastructure necessary for reclamation; preparation of the landscape and construction of engineering systems that contribute to the further functioning of the reclaimed land ${ }^{\dagger}$.

The task of the next "biological" stage is the formation of the vegetation cover itself. At this stage, the future purpose of the reclaimed lands (agricultural, forestry, water management, recreational, etc.) is selected, the humus layer is replaced, mineral and organic fertilizers are applied, types of vegetation are selected based on the natural and climatic conditions of the territory, and then they are planted.

It should be noted that this stage is also performed in two steps. Initially, "pioneer" crops are planted, which easily adapt to difficult conditions and have a special regenerative ability. Then there is a planting of plants that meet the intended purpose of the land. After that, the stage of active recovery begins: the rate of soil formation increases, their nutritional and water regimes improve, and the formation of a stable vegetation cover begins naturally.

On average, it takes 2 to 3 years to restore the natural potential, depending on the initial conditions (land area, degree of pollution, disturbance of the soil structure, etc.). In critical situations, this figure can reach several decades. However, even in spite of the fact that such

\footnotetext{
$\dagger$ At the same time, the type of such systems often depends on the intended purpose of the cultivated land: for agricultural - reclamation, for fishery - pond, and so on.
} 
works are long and very expensive, they should be carried out, since the benefits from them in the future will significantly exceed all costs.

\section{Research methods}

The technical and economic plan of reclamation works for the considered object consists of the following stages.

Technical stage:

1. Extraction of gold-bearing soil from the surface of the tailing dump (extraction depth $-3 \mathrm{~m}$ ). For extraction, it is planned to purchase our own equipment (dump trucks, excavators) and hire workers;

2. Delivery of the extracted soil to a modular processing complex for the extraction of gold concentrate. A similar complex is planned to be purchased from one of the Russian companies engaged in the production of mining equipment;

3. Flattening and terracing, levelling of the pit bottom;

4. Laying out recycled land and levelling the surface;

5. Creation of a protective screen.

The biological stage consists in the application of $25 \mathrm{~cm}$ of the fertile layer of the earth, in its enrichment with the necessary micro and macro-elements, as well as in the subsequent planting of seeds. At the same time, the staff of the institute gave recommendations on introducing additional components into the soil for more effective detoxification of soils and increasing its fertility, namely: biochar, hydrogel, bentonite and various substrates.

Due to its porous surface, biochar can be used as a technical sorbent, which allows it to participate in the process of soil detoxification. This is especially important in the case of heavy metal contamination. The recommended amount of application, according to experts, is $30 \%$ of the total volume of the fertile layer. The cost of adding $1 \mathrm{~kg}$ is 7.5 rubles.

As a solution to the problems of replenishing substrates in the soil and introducing a hydrogel, it was proposed to apply a hydro seeding mixture. This method is effective for creating dense, grass cover and restoring disturbed lands. The mixture includes hydrogel, which is a water-retaining additive; a fixer that works as an adhesive; a complex of fertilizers (regulators of acidity, growth, necessary macro-and microelements). Average consumption per 10,000 sq. $\mathrm{m}$ - about $140 \mathrm{~kg}$. The cost of adding $1 \mathrm{~kg}$ is 679 rubles.

Instead of adding bentonites, the decision was made to lay bentomates that could replace the traditional geomembrane layer used in remediation. They are also more advanced in terms of technology: they are easier to install, they do not require welding, they are more durable, frost-resistant, have greater strength and environmental friendliness, have high waterproofing properties, and have regenerative properties. It is by far the most effective soil-protecting filter screen. The cost of laying per 1 sq. $\mathrm{m}$ is 500 rubles.

When choosing a seed mixture for reclamation, the recommendations of ecologists who had previously conducted experimental observations of the most suitable crops for revegetation were also taken into account. Thus, in the course of the experiments, it was found that among the crops that adapt well to the climatic conditions of Western Siberia and contribute to the restoration of soils, red fescue and birch stand out.

Thus, for the subsequent landscaping, a mixture was chosen that is especially effective in temperate conditions. In addition to the recommended birch and fescue, there were such crops as awnless rump, wheatgrass, ryegrass, annual ryegrass, red meadow clover and yellow sweet clover. The seeds of these plants are resistant to heavy metals, salt-tolerant and can absorb gases. The cultivation of the proposed plants will contribute to the restoration of the physicochemical composition of soils and prevent their erosion. The consumption of such a mixture is about $45 \mathrm{~kg}$ per hectare. The cost of $1 \mathrm{~kg}$ is 3000 rubles. 
It should be noted that to start the work, it is necessary to resolve some problems associated with the lack of the necessary infrastructure. These limitations are lack of power supply system, water canal and floodlighting of the tailing dump. To solve the problem of providing the power supply, it is necessary to install additional supports for the power transmission line (hereinafter - power lines), carry out additional ones; obtain permission to connect to the main power plant, purchase metering devices and distributors. To provide access to water, it is necessary to install a caisson, a pump and a hydraulic accumulator, automation systems and lay a pipeline. It was decided to circumvent the lighting problem due to the large area by purchasing mobile lighting masts on sledges, which are used in quarries and places with no roads.

Another obligatory item in the feasibility study of reclamation measures was the calculation of the costs of the reproduction of labour resources. Here we included the wages of employees (shift supervisor, excavator and dump truck drivers, mechanics of processing complexes, a security guard and a cook), who are supposed to be hired on a rotational basis. Other expenses of this item include the purchase of residential trailers, a checkpoint trailer, an office, a dining trailer, workwear and energy costs.

Additionally, it is required to take into account transport costs, possible costs of equipment repair. It was decided to create a reserve for repair work, amounting to an average of $10 \%$ of the original cost of the equipment [3].

The last point of the project represents the revenue part from the sale of gold mined during processing (according to experts-geologists, the volume will be approximately 1,700 $\mathrm{kg}$ ), as well as income from the resale of equipment operated during the work. The cost of equipment is determined taking into account depreciation on a straight-line basis.

\section{Results and discussion}

Following the technology defined by the GOST standard as the best, a technical and economic plan for reclamation work was drawn up. The calculations were made using the Excel software package based on the analysis of literature [4-8] and legislative standards for remediation. The following are the results of calculations for the project. Thus, for the implementation of the project, it is planned to purchase equipment (Table 1).

Table 1. Buying your own equipment

\begin{tabular}{|c|c|c|c|c|}
\hline Expenditure item & Attachments item & Price, rub. & Amount & Total cost, rub. \\
\hline $\begin{array}{c}\text { Extraction of gold- } \\
\text { bearing soil from } \\
\text { the surface of the } \\
\text { tailing dump }\end{array}$ & $\begin{array}{c}\text { Dump truck BELAZ } \\
75172\end{array}$ & 45000000 & 2 & 90000000 \\
\cline { 2 - 4 } & $\begin{array}{c}\text { Liebherr R9250 } \\
\text { excavator }\end{array}$ & 25000000 & 2 & 50000000 \\
\hline $\begin{array}{c}\text { Soil processing at } \\
\text { the processing } \\
\text { complex }\end{array}$ & $\begin{array}{c}\text { Concentrating } \\
\text { complex OKV-100 }\end{array}$ & 22000000 (cost) & $\begin{array}{c}3000000 \\
\text { (installation) }\end{array}$ & 35000000 \\
\cline { 2 - 3 }
\end{tabular}

Source: Authors' estimates

According to our calculations, the total costs for the technical stage will amount to about

167 million rubles. The biological stage will require a total investment of 160 million rubles. The cost of creating and using infrastructure - 38.7 million rubles. Fuel costs for the BELAZ 75172 Dump Truck, the Liebherr R9250 Excavator and lighting are 54.6 million rubles. Personnel costs, in turn, will amount to 5.307 million rubles. Income from the sale of equipment and mined gold -3.926 billion rubles. Finally, the project overhead will 
amount to 63.1 million rubles. Thus, the total project costs will be equal to 716.6 million rubles, taking into account discounting (Table 2).

Table 2. The total cost of work on reclamation of disturbed lands on the territory of the Komsomolsk tailing dump, rubles.

\begin{tabular}{|l|l|}
\hline Total expenses & 716618409 \\
\hline Total income & 3926099130 \\
\hline Total profit from reclamation & 3209480721 \\
\hline
\end{tabular}

The authors also determined the total assessment of environmental damage from the activities of the Komsomolsk gold recovery plant - 458.182 million rubles. (2020). When calculating the assessment of the amount of accumulated environmental damage caused to water resources, the degree of water pollution in the technogenic lake "Berkom" of the Komsomolsk tailing dump was taken into account. The accumulated environmental damage from the pollution of this water body is 293.9 million rubles.

The assessment of environmental damage caused to soils, taking into account the degree of accumulated pollution of all metals in the soil, according to calculations, amounted to 164.4 million rubles.

The estimate of environmental protection measures, taking into account discounting, amounted to 716.7 million rubles. At the same time, the proceeds from the sale of equipment and mined gold amounted to 3.9 billion rubles.

\section{Conclusions}

More than one and a half thousand manufacturing enterprises are concentrated in a small territory of Kuzbass. In terms of emissions and discharges of pollutants into the environment, the region ranks eighth in the rating of the "dirtiest" regions of Russia. Longterm exploitation of the territory by heavy industry sectors led to the formation of significant environmental damage on it. This damage is expressed in the form of lands disturbed by mine workings, contaminated and degraded lands under the enterprises of the chemical and metallurgical industries.

This disastrous ecological situation forces the local administration to allocate a sufficient part of the budget for environmental protection and restoration activities. So, in 2018, the regional administration spent almost 11 billion rubles for these needs, which is $1 \%$ of the GRP, which is much higher in comparison with the average value for the regions of Russia and the total share of environmental expenditures in the federal budget, equal to $0.71 \%$ Of GDP. Unfortunately, even despite the higher average spending on environmental needs, these funds are not enough to cover the damage caused by enterprises in the region's ecology.

The issue of financing these activities is also quite acute. As can be seen from the calculations, restoration work requires huge investments, but the expected profit is many times higher than their cost. Even though the project is highly profitable, it is not worth implementing it as part of a private initiative, since earlier in 2011 there were precedents when $400 \mathrm{~kg}$ of gold were extracted from the quarry, but the environmental situation at the tailing dump only worsened. For this reason, when carrying out work, it is worth paying special attention to state control or carrying out work within the framework of a publicprivate partnership.

Acknowledgements: The work was supported by Grant of Russian Federation President for young scientists № MK-1819.2020.6 and the basic project of laboratory 1105 No. 0266-2019-0008. 


\section{References}

1. V. Vigdorovich, N. Gabelko, Technogenic Systems and Environmental Risk (G.R. Derzhavin State University, Tambov, 2004)

2. N. Kamordzhanova, I. Kartashova, Financial accounting, (St. Petersburg, 2003)

3. S. Friedland, Environmental Engineering, 5 (2009)

4. G.H. Du Pleiss, J.A. Swartz, Water Science Technology, 25, 193-201 (1992)

5. T. Mitrakova, Application of materials of natural origin for sorption treatment of wastewater from copper ions: dissertation abstract (2017)

6. G.V. Lepesh, Technical and technological problems of service, 3(37), 3-5 (2016)

7. L. Eder, I. Filimonova, V. Nemov, A. Komarova, and K. Sablin, E3S Web Conf., 80, 03010 (2019)

8. I. Filimonova, A. Komarova, and M. Mishenin, Oc 11(2), 309-324 (2020)

9. L. V. Eder, I. V. Provornaya, I. V. Filimonova, V. D. Kozhevin, and A. V. Komarova, Energy Procedia 153, 112-117 (2018)

10. L. V. Eder, I. V. Provornaya, and I. V. Filimonova, Geogr. Nat. Resour. 40, 9-14 (2019) 